\title{
E pluribus plurima: Multidimensional indices and clinical phenotypes in COPD
}

\author{
Andrea Rossi and Erika Zanardi
}

Chronic Obstructive Pulmonary Disease (COPD) is a disorder of the respiratory system characterized by progressive and only partially reversible airflow obstruction, due to a varying combination of large (bronchitis) and small airways (small airway disease) damage, and lung parenchymal and vascular destruction [1]. We prefer the term obstruction to airflow limitation because the latter is a physiologic event which occurs also in normals at high levels of ventilation, for example during exercise. The correct definition should be "excessive airflow limitation" to indicate that the reduction in airflow occurs at lower level of ventilation than in normal condition. The diagnostic procedure for COPD starts from the recognition of risk factors (cigarette smoking "in primis", but also outdoor and indoor air pollution [2]) and the presence of symptoms such as chronic cough and phlegm and reduced exercise tolerance. The lifestyle is important for the reveal of symptoms: dyspnea occurs later in a sedentary person than in an active individual.

The objective demonstration of airflow obstruction by spirometry is mandatory to establish the diagnosis. A post-bronchodilator FEV1/FVC $<0.70$ is considered sufficient to define airflow obstruction and to confirm the diagnosis $[3,4] . F V C=$ forced vital capacity; FEV1 = forced expiratory volume in the 1 st second; $\mathrm{VC}=($ slow $)$ vital capacity. Some Guidelines requires that FEV1/FVC $<0.70$ [5] should be associated with a FEV1 $<80 \%$ of the predicted value [1,6]. Many Authors [7], however, and some official documents $[8,9]$ do not accept the fixed "cut-off" and indicate the FEV1/VC < lln (lower limit of normality) as a more correct documentation of airflow obstruction. The debate is still ongoing [10]. However, it seems to be a general agreement to use the value of FEV1\%predicted to stage the severity of the disease. Neverthless, it would be more appropriate to accept the use of that measurement for staging only the severity of airflow obstruction, not the whole disease state. In fact COPD is a heterogeneous

\footnotetext{
* Correspondence: andrea.rossi2@ospedaleuniverona.it

Pulmonary Unit, Cardiovascular and Thoracic Department, University and General Hospital, P.le Stefani 1, I-37126, Verona, Italy
}

disorder with diverse pathophysiological manifestations at the level of the respiratory system as well as at systemic level with complications and comorbidities. Not surprisingly, the FEV1 is rather insufficient to assess the status and progress of the disease as well as the effects of therapies. Although very helpful and valuable, the FEV1 has several limitations which should be taken into account when interpreting its value and changes.

First of all it should be remembered that FEV1 results from two undisclosed determinants, i.e. the caliber of the large airways and the lung elastic recoil. The latter is poorly sensitive to treatments whereas the former can be improved by either pharmacological [11] and/or non pharmacological [12] treatments. Therefore, the individual response to therapies depends upon which determinant drives the FEV1 reduction more. Furthermore, the FEV1 is rather insensitive to small airway disease, which is an important pathology of COPD [13] and may be extensively present when spirometry is still within the normal range [14].

\section{Respiratory pathophysiology}

Airflow obstruction is the hallmark of COPD. However, the pathophysiology of COPD is intricate. In fact, it encompasses also pulmonary hyperinflation and nonuniform distribution of ventilation [15]. Lung hyperinflation has two components:

- static, i.e. the increase in functional residual capacity (FRC) due to the loss of lung elastic recoil because of destruction of lung parenchyma, and

- dynamic, i.e. the position of the end-expiratory lung volume above the relaxed volume of the respiratory system, (for example during exercise or exacerbations).

Hyperinflation may be a predictor of mortality when expressed as IC/TLC\%. IC = inspiratory capacity; TLC = total lung capacity [16].

Small airways disease and parenchymal destruction result in maldistribution of ventilation leading to ventilation-perfusion mismatching and eventually causing lung failure and hypoxemia. On the other hand, pulmonary 
hyperinflation reduces the pressure generating capacity of the respiratory muscles eventually leading to ventilatory pump failure, and hypercapnia [17]. None of these pathophysiologic events is correlated to the changes in FEV1, which, at the same time, is poorly related to exercise capacity and symptoms intensity. However, this elaborate respiratory pathophysiology is not the end of the COPD heterogeneous picture. Systemic effects must be taken into account to understand correctly the real severity of the disease in different patients.

\section{Systemic effects}

The skeletal muscles are affected unfavourably by COPD. Exercise intolerance worsens with the progression of the disease [18]. Obviously, the first individual reaction is to prevent that "unpleasant sensation of difficult breathing" (i.e. dyspnea) by limiting exercise and life activity. Under those circumstances, skeletal muscles undergo progressive deconditioning and the vicious circle is elicited: dyspnea - activity limitation - muscle deconditioning dyspnea [19]. Often, malnutrition can aggravate the loss of skeletal muscles force.

Chronic cor pulmonale is a well known complication of advanced COPD. However, a recent large, population based study has shown that impaired left ventricular filling, reduced stroke volume, and lower cardiac output were linearly related to the extent of emphysema at the $\mathrm{CT}$ scanning and to the severity of spirometric airflow obstruction [20]. However, in that study, the FEV1/FVC ratio was, on average, above 0.64 , a value only slightly below the 0.70 limit accepted as normal. Therefore, the cardiovascular system in COPD patients is challenged not only by the common risk factor, i.e. cigarette smoking, but also by emphysema at earlier stages than traditionally thought.

\section{Exacerbations}

The assessment of COPD severity cannot ignore the occurrence of exacerbations, which are a prominent feature of the natural history of COPD. They influence the progression of the disease and are a major cause of morbidity and mortality, and socio-economic cost [21]. Many data support the conclusion that exacerbations are more frequent and more severe in patients with advanced airflow obstruction. However, the ECLIPSE study [22] found that although exacerbations become more frequent and more severe as COPD progresses, the rate at which they occur appears to reflect an independent susceptibility phenotype.

Therefore, it is not surprising that a single variable, such as for example the FEV1, cannot capture the heterogeneity of COPD, both pulmonary and systemic [23]. In addition, the individual patient with COPD is often affected by comorbidities, because other diseases are common at the age when COPD becomes clinically revealed, for example systemic arterial hypertension, diabetes, obesity etc.

In summary, the modern approach to the COPD patient goes beyond the necessary demonstration of airflow obstruction and the understanding of the complex pulmonary pathophysiology to embody the systemic effects and comorbidities [24,25]. This view encouraged the development of multidimensional indices to provide physician with some robust instrument to ascertain the status and progress of the disease as well as to guide therapy in the individual patient.

In this issue of Respiratory Research, Wouter D. van Dijk and colleagues [26] provide a systematic review of 15 multidimansional indices selected in 13 studies from > 7000 articles screened in the Pubmed and Embase literature database. This laudable effort concluded however that "although the prognostic performance of the indices has been validated, they all lack sufficient evidence on implementation". Obviously it is not an Authors' fault. It is the discrepancy between the complexity of the disease and the need to find something measurable to be helpful, clear, and easy for its use in the clinical practice. The population based prediction might be improved by some indices which may however lack feasibility in the real life of the individual patient-doctor relationship. A good example of this dilemma is the FEV1 decline. Since the classic study by Fletcher and colleagues $[27,28]$ it is widely accepted that the rate of decline of the FEV1 might be regarded as a marker of the progression of COPD related to important outcomes such as disability and death [29]. However, the starting point of the FEV1 might be influenced by the impact of factors, not related to COPD, in early life or even in the pre-birth period on adult lung function. Furthermore, the rate of decline of the FEV1 cannot be used in the clinical practice because it would require a minimum of observation for two years, with at least threefour measurements of FEV1 per year: the first year to compute the baseline decay and the second year, after the start of the treatment, to document the slowdown of the decay. Rather impractical!

Great expectations are generated by molecular and genomic research [30]. The result of gene-environment interactions determines the clinical presentation of the disease: the clinical phenotype. It might be that a better identification of COPD phenotypes would lead to identification of specific indices customized to a particular phenotype. The traditional classification of COPD phenotypes pertains to the classic "blue-bloater" and "pinkpuffer" pictures [31]. However, it has been suggested already several years ago that many patients fall into neither group and that those descriptive terms are not clearly related to specific functional or pathologic features. Therefore its use is not encouraged [8]. By contrast, other phenotypes have been recommended. The 
ECLIPSE study suggests the "frequent exacerbator" phenotype [32-34], which could be further classified into three "clinical phenotypes" termed bacteria-associeted, virus-associeted and eosinophil-associeted [34]. This has meaningful implication for clinical practice for both the therapeutic approach $[21,35]$ and the choice of the multidimensional index, which should include the exacerbation occurrence. For example, the DOSE [36] might apply better to this phenotype rather than to the general COPD population.

Currently, COPD and asthma are differentiated, but we all accept that some areas of overlap exist. Their recognition may influence the therapeutic decision, for example the use of inhaled corticosteroids [3,37,38]. Lung function tests such as assessment of airway reactivity [39] or measurement of single-breath carbon monoxide transfer factor (TL,CO) $[8,40]$ could be particularly useful to monitor this segment of patients. In some cases the detection of eosinophilic sputum might be useful [41].

The analysis of data from large, longitudinal studies has brought to attention the fact that FEV1 decline is not uniform throughout the progression of the disease but it may be larger at early stage, when there is more to lose, and smaller in the advanced stage when it remains little to be lost $[42,43]$. A subgroup of so called "rapid decliner" $[44,45]$ might reflect another phenotype of the disease. In this subgroup, or clinical phenotype, repeated measurement of FEV1 could be much more valuable than in other sub-groups.

In conclusion, as the picture of COPD becomes more complex and the results from large studies generate the need of further research, it is clear the close link between the definition of clinical phenotypes and the validation of either single or multidimensional indices. The line of search marker, either biological or physiological, for one COPD has come to its end. The definition of multiple clinical phenotype crosses repeatedly and systematically the evolution of indices and markers. From the crossmatching of multiple phenotypes and multidimensional indices we cannot expect the birth of a single variable to assess the heterogeneous COPD, but multiple variables for different COPDs: "e pluribus plurima".

Received: 24 October 2011 Accepted: 14 November 2011

Published: 14 November 2011

\section{References}

1. National Clinical guideline Centre: Chronic obstructive pulmonary disease: management of chronic obstructive pulmonary disease in adults in primary and secondary care. London: National Clinical Guideline Centre; 2010 [http://guidance.nice.org.uk/CG101/Guidance/pdf/English].

2. Salvi SS, Barnes PJ: Chronic obstructive pulmonary disease in nonsmokers. Lancet 2009, 374:733-743.

3. GOLD: Global Initiative for Chronic Obstruction Lung Disease. Global Strategy for diagnosis, management, and prevention of chronic obstructive pulmonary disease 2010 [http://www.goldcopd.com].
4. Celli BR, MacNee W: Standard for the diagnosis and treatment of patients with COPD: a summary of the ATS/ERS position paper. Eur Respir J 2004, 23:932-946.

5. Vestbo J, Rodriguez-Rosin R: GOLD and the fixed ratio. Eur Respir J 2011, 38:481-2.

6. O'Donnell DE, Aron S, Bourbeau J, Hernandez P, Marciniuk D, Balter M, Ford G, Gervais A, Goldstein R, Hodder R, Maltais F, Road J: Canadian Thoracic Society Recommendations for Management of Chronic Obstructive Pulmonary Disease - 2003. Can Respir J 2003, 10(Suppl A):11A-33A.

7. Quanjer PH, Enright PL, Miller MR, Stocks J, Ruppel G, Swanney MP, Crapo RO, Pedersen OF, Falaschetti E, Schouten JP, Jensen RL: The need to change the method for defining mild airway obstruction. Eur Respir $J$ 2011, 37:720-722.

8. Siafakas NM, Vermeire P, Pride NB, Paoletti P, Gibson J, Howard P, Yernault JC, Decramer M, Higenbottam T, Postma DS, Rees J, on behalf of the Task Force: Optimal assessment and management of chronic obstructive pulmonary disease (COPD). Eur Respir J 1995, 8:1398-1420.

9. Pellegrino R, Viegi G, Brusasco V, Crapo RO, Burgos F, Casaburi R, Coates A, van der Grinten CP, Gustafsson P, Hankinson J, Jensen R, Johnson DC, Maclntyre N, McKay R, Miller MR, Navajas D, Pedersen OF, Wanger J: Interpretative strategies for lung function tests. Eur Respir J 2005, 26:948-968.

10. MacNee W: Clinic Practice Guidelines: more of the same? Am J Respir Crit Care Med 2001, 184:492-494.

11. Tashkin DP, Celli B, Senn S, Burkhart D, Kesten S, Menjoge S, Decramer M, UPLIFT Study Investigators: A 4-year trial of triotropium in chronic obstructive pulmonary disease. N Engl L Med 2008, 359:1543-54.

12. Washko GR, Fan VS, Ramsey SD, Mohseinifar Z, Martinez F, Make BJ, Sciurba FC, Criner GJ, Minai O, Decamp MM, Reilly JJ, National Emphysema Treatment Trial Research Group: The effect of lung volume reduction surgery on chronic obstructive pulmonary disease exarcerbations. Am J Respir Crit Care Med 2008, 177:164-169.

13. Hogg JC, Chu F, Utokaparch S, Woods R, Elliot WM, Buzatu L, Cherniack RM Rogers RM, Sciurba FC, Coxson HO, Paré PD: The nature of small-airway obstruction in chronic obstructive pulmonary disease. N Engl J Med 2004 350:2645-2653

14. Irving CG: Will the small airways rise again? Am J Respir Crit Care Med 2011, 184:499-500

15. Reilly JJ, Silverman EK, Shapiro SD: COPD. Harrison's principles of internal medicine. 17 edition. McGrowHill, NYC, NY; 2008

16. Casanova C, Cote C, De Torres JP, Aguirre-Jaime A, Marin JM, Pinto-Plata V, Celli BR: Inspiratory-to-Total lung capacity ratio predicts mortality in patients with chronic obstructive pulmonary disease. Am J Respir Crit Care Med 2005, 171:591-597.

17. Roussos C, Macklem PT: The respiratory muscles. N Eng J Med 1982, 307:786-97.

18. O'Donnel DE: Hyperinflation, dyspnea, and exercise intolerance in chronic obstructive pulmonary disease. Proc Am Thorac Soc 2006, 3:180-184

19. Cooper CB: The connection between chronic obstructive pulmonary disease symptoms and hyperinflation and its impact on exercise and function. Am J Med 2006, 119(Suppl 1):21-31.

20. Barr RG, Bluemke DA, Ahmed FS, Carr JJ, Enright PL, Hoffman EA, Jiang R, Kawut SM, Kronmal RA, Lima JA, Shahar E, Smith LJ, Watson KE: Percent emphysema, airflow obstruction, and impaired left ventricular filling. $N$ Engl J Med 2010, 362:217-27.

21. Siafakas NM: Preventing exacerbations of COPD - Advice from Hippocrates. N Engl J Med 2001, 356:753-4.

22. Hurst JR, Vestbo J, Anzueto A, Locantore N, Mullerova $H$, Tal-Singer $R$, Miller B, Lomas DA, Agusti A, Macnee W, Calverley P, Rennard S, Wouters EF, Wedzicha JA, Evaluation of COPD Longitudinally to Identify Predictive Surrogate Endpoints (ECLIPSE) Investigators: Susceptibility to exacerbation in chronic obstructive pulmonary disease. $N$ Engl J Med 2010, 363:1128-1138

23. Augusti A, Calverly PMA, Celli B, Coxson HO, Edwards LD, Lomas DA, MacNee W, Miller BE, Rennard S, Silverman EK, Tal-Singer R, Wouters E, Yates JC, Vestbo J, Evaluation of COPD Longitudinally to Identify Predictive Surrogate Endpoints (ECLIPSE) investigators: Characterization of COPD heterogeneity in the ECLIPSE cohort. Respir Res 2010, 11:122 
24. Walter RE, Wilk JB, Larson MG, Vasan RS, Keaney JF Jr, Lipinska I, O'Connor GT, Benjamin EJ: Systemic inflammation and COPD. The Framingham Heart Study. Chest 2008, 133:19-25.

25. Fabbri LM, Rabe KF: From COPD to chronic systemic inflammatory syndrome? Lancet 2007, 370:797-99.

26. van Dijk WD, van den Bemt $L$, van den Haak-Rongen $S$, Bischoff $E$, van Weel C, Veen JCCM, Schermer TRJ: Multidimensional prognostic indices for use in COPD patient care. A systematic review. Respir Res 2011.

27. Fletcher C, Peto R, Tinker C, Speizer FE: The Natural history of chronic bronchitis and emphysema. Oxford University Press. Oxford; 1976.

28. Fletcher C, Peto R: The Natural history of chronic airflow obstruction. $\mathrm{Br}$ Med J 1977, 1:1645-1648.

29. Cazzola M, MacNee W, Martinez FJ, Rabe KF, Franciosi LG, Barnes PJ, Brusasco V, Burge PS, Calverley PM, Celli BR, Jones PW, Mahler DA, Make B, Miravitlles M, Page CP, Palange P, Parr D, Pistolesi M, Rennard SI, Rutten-van Mölken MP, Stockley R, Sullivan SD, Wedzicha JA, Wouters EF, on behalf of the American Thoracic Society/European Respiratory Society Task Force on outcomes of COPD: Outcomes for COPD pharmacological trials: from lung function to biomarkers. Eur Respir J 2008, 31:416-468.

30. Augusti A, Vestbo J: Current controversies and future perspectives in COPD. AJRCCM 2011

31. Netter FH: Atlas of human anatomy. In Pulmonary Chronic Obstructive Disease. Volume 4. Ciba Collection; 1980:148-149.

32. Tashkin DP: Frequent exacerbation of COPD a distinct phenotypes? N Engl J Med 2010, 363:1183-4.

33. Parr DG: Patient phenotyping and early disease detection in chronic obstructive pulmonary disease. Proc Am Thorac Soc 2011, 8:338-349.

34. Hurst JR: Exarcerbation phenotyping in chronic obstructive pulmonary disease. Am J Respir Crit Care Med 2011, 184:625-626.

35. Albert RK, Connett J, Bailey WC, Casaburi R, Cooper JAD, Criner GJ, Curtis JL, Dransfield MT, Han MK, Lazarus SC, Make B, Marchetti N, Martinez FJ, Madinger NE, McEvoy C, Niewoehner DE, Porsasz J, Price CS, Reilly J, Scanlon PD, Sciurba FC, Scharf SM, Washko GR, Woodruff PG, Anthonisen NR, COPD Clinical Research Network: Azithromycin for prevention of exacerbation of COPD. N Engl J Med 2011, 365:389-98.

36. Rupert CJ, Donaldson GC, Chavannes NH, Kida K, Dickson-Spillmann M, Harding S, Wedzicha JA, Price D, Hyland ME: Derivation and validation of Composite Index of severity in chronic obstructive pulmonary disease. The DOSE index. Am J Respir Crit Care Med 2009, 180:1189-95.

37. Postma DS, Calverly P: Inhaled corticosteroids in COPD: a case in favor. Eur Resp J 2009, 34:10-12.

38. Suissa S, Barnes PJ: Inhaled corticosteroids in COPD: the case against. Eur Respi J 2009, 34:13-16.

39. Lapperre TS, Snoeck-Stroband JB, Gosman MME, Jansen DF, van Schadewijk A, Thiadens HA, Vonk JM, Boezen HM, Ten Hacken NH, Sont JK, Rabe KF, Kerstjens HA, Hiemstra PS, Timens W, Postma DS, Sterk PJ, Groningen Leiden Universities Corticosteroids in Obstructive Lung Disease Study Group: Effect of fluticasone with and without salmeterol on pulmonary outcomes in chronic obstructive pulmonary disease: a randomized trial. Ann Intern Med 2009, 151:517-27.

40. Fabbri LM, Romagnoli M, Corbetta L, Casoni G, Busljetic K, Turato G, Ligabue G, Ciaccia A, Saetta M, Papi A: Differences in airway inflammation in patients with fixed obstruction due to asthma or chronic obstructive pulmonary disease. Am J Respir Crit Care Med 2003, 167:418-424.

41. Brightling CE, McKenna S, Hargadon B, Birring S, Green R, Siva R, Berry M, Parker D, Monteiro W, Pavord ID, Bradding P: Sputum eosinophilia and short term response to inhaled mometasone in chronic obstructive pulmonary disease. Thorax 2005, 60:193-198.

42. Decreamer M, Celli B, Kesten S, Lystig T, Mehra S, Tashkin DP, for the UPLIFT investigators: Effect of tiotropium on outocomes in patients with moderate chronic obstructive pulmoanry disease (UPLIFT): a prespecified subgroup analysis of a randomized controlled trails. Lancet 2009, 374:1171-8.

43. Celli $B$, Thomas NE, Anderson JA, Ferguson GT, Jenkins CR, Jones PW, Vestbo J, Knobil K, Yates JC, Calverley PM: Effect of pharmacotherapy on rate of decline of lung function in chronic obstructive pulmonary disease: results from TORCH study. Am J Respir Crit Care Med 2008, 178:332-338

44. Kohansal R, Martinez-Camblor P, Augusti A, Buist AS, Mannino DM, Soriano JB: The natural history of chronic airflow obstruction revisited: an analysis of the Framingham offspring cohort. Am J Respir Crit Care Med 2009, 180:3-10.

45. Renanrd SI, Vestbo J: Natural histories of chronic obstructive pulmoanry disease. Proc Am, Thorac Soc 2008, 8:878-883.

doi:10.1186/1465-9921-12-152

Cite this article as: Rossi and Zanardi: E pluribus plurima:

Multidimensional indices and clinical phenotypes in COPD. Respiratory

Research 2011 12:152.

\section{Submit your next manuscript to BioMed Central and take full advantage of:}

- Convenient online submission

- Thorough peer review

- No space constraints or color figure charges

- Immediate publication on acceptance

- Inclusion in PubMed, CAS, Scopus and Google Scholar

- Research which is freely available for redistribution

Submit your manuscript at www.biomedcentral.com/submit
Biomed Central 